\title{
HUMANIZED CHILDBIRTH: A TRANSDICIPLINARY REVIEW
}

\author{
Fernanda Cessel Marques ${ }^{1}$, João Vítor Mendes Vilela ${ }^{1}$, Emanoel Nascimento Costa ${ }^{1}$, \\ Kenne Samara Andrade 1, Nayra Carla de Melo 1, Eduardo J.S. Honorato $\mathbb{\Xi}_{1}$, e Sônia \\ Maria Lemos ${ }^{1}$ \\ ${ }^{1}$ Amazonas State University, Brazil
}

DOI: https://doi.org/10.29121/granthaalayah.v8.i7.2020.574

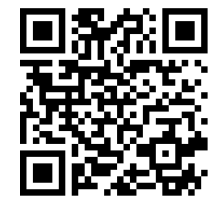

Article Type: Research Article

Article Citation: Fernanda Cessel Marques, João Vítor Mendes Vilela, Emanoel Nascimento Costa, Kenne Samara Andrade, Nayra Carla de Melo, Eduardo J.S. Honorato, and e Sônia Maria Lemos. (2020). HUMANIZED CHILDBIRTH: A TRANSDICIPLINARY REVIEW. International Journal of Research GRANTHAALAYAH, 8(7), 1-16. https://doi.org/10.29121/granthaa layah.v8.i7.2020.574

Received Date: 28 June 2020

Accepted Date: 22 July 2020

Keywords:

Humanized Birth

Obstetric Violence

Childbirth Assistance

\section{ABSTRACT}

The Humanized Childbirth movement is characterized by the intellectual, technical, and professional union of several areas that focus on the quality of care received by pregnant women, babies, and family members during the process of childbirth. In the last four decades, specific knowledge about the birth process has undergone several updates, mainly concerning less interventionist assistance. However, in many contexts, labor is still seen as pathological or non-physiological and culminates in questionable interventions in the female body. This profound distortion in childbirth care is determined by multiple historical, structural, and cyclical factors that directly affect the way society in general and the health area, in particular, face the female sex. Thus, it is imperative to critically discuss childbirth care with contextualization of gender, cultural, structural, and scientific issues (Evidence-Based Medicine) to guarantee the protection of the person about violations of sexual and reproductive rights. The approach of this literature review focused on the multiple meanings of the humanization process of childbirth care, with the concern of being transdisciplinary.

\section{INTRODUCTION}

For centuries women have been fighting several battles in the search for spaces and rights in society, most of them fundamental and inherent to human beings, denied by patriarchalism. Meanwhile, they still carry a massive load of gender prejudices in labor, sexual, and even reproductive spheres. Despite the diverse achievements of feminist social movements, women still do not enjoy the fullness of their recognized and realized rights. The problem lies in the structures of an idealized society, conceptualized and led by men, who instrumentalize the role of women and thus, in a veiled way, thoughts of interiorization of beings antagonistic to cis and straight men are perpetuated.

Within this context, medicine appropriated knowledge about the female body and proclaimed itself as the legitimate holder of this knowledge [1]. This appropriation relegated pregnant women to a supporting and extremely passive role in the parturition process [1].

Since the end of the 20th century, there has been social mobility that seeks to restore female protagonism in conception. In this sense, the expression "humanization of childbirth" has been used by the Brazilian Ministry of Health to refer to a series of public policies promoted with the support of the World Health Organization (WHO), the

(C) 2020 The Author(s). This is an open access article distributed under the terms of the Creative Commons Attribution License, which permits unrestricted use, distribution, and reproduction in any medium, provided the original author and source are credited. 
Pan American Health Organization ( $\mathrm{PAHO}$ ) and the World Bank and with the collaboration or partnership of various social actors, such as NGOs and professional entities [2].

Given the diversity of social actors and interests involved, it is not surprising that there is a series of conflicts around different conceptions of childbirth. There are controversies about which professional is more qualified; what equipment is indispensable; how to provide security for delivery in which locations; reproductive rights, including the right to choose; and, more recently, the technical guidelines that should guide obstetric practice. Thus, around the meaning of "humanization," with regard specifically to obstetric care, there is a field of disputes and negotiations [2].

The Humanized Childbirth movement is characterized by the intellectual, technical, and professional union of several areas that excel in the quality of care received by women, babies, and family members during the delivery and birth. The personal experience, both physical and emotional, of those involved in this process, is valued, based on scientific and psycho-emotional data, which offer strong evidence on the short and long term effects of such experiences [3].

Based on the scientific validation of this proposal and its experience in other countries, the Humanization Program for Prenatal and Birth was established in Brazil within the scope of the Unified Health System (SUS), by Ordinance No. 569 / GM, from the Brazilian Ministry of Health (MS). It takes into account the duties of Providing pregnant women and newborns with dignified and quality care; Reduce high rates of maternal, perinatal and neonatal morbidity and mortality; Improve access, coverage, and quality of prenatal care, delivery and postpartum care and neonatal care; Improve health care for pregnant women at the outpatient, primary and specialized levels; Integrate all levels of assistance to pregnant women, childbirth and newborns; Implement Obstetric and Neonatal Regulation Centers at the state, regional and municipal levels, with prompt and qualified care, according to the demand of the specific population, that is, the pregnant woman and the newborn. Therefore humanization in childbirth care is a women's health policy that aims to adapt the infrastructure, the team, and the conduct in pre/trans/ postpartum care, in addition to ensuring the implementation of our Health System principles [4].

In the last four decades, in Brazil, the specific knowledge around the birth/birth process has undergone several changes, mainly in the way delivery should be conducted and assisted. Among these changes, hospitalization and medical interventions stand out to ensure a fast birth process, which would theoretically allow a healthier birth and greater maternal comfort. Also, the disrespectful service (which is mainly aimed at trans people, black people, drug users, people living with HIV and those with less socio-economic status), by many health professionals during vaginal delivery leads pregnant women to choose for a "more dignified" form of birth for their children ${ }^{5}$. The vaginal delivery became associated with the outdated and violence against the female body, which naturalized the preference for cesarean section under a hopeful perspective of reducing pain and suffering [5].

However, the overemphasis in the indications for surgical delivery led to an increase in maternal morbidity and mortality, as well as an increase in the consumption of costly resources in the health system. In contrast, new studies reduce indications for surgical delivery, as well as techniques that speed up vaginal delivery. However, few institutions and health professionals have already adapted their routines to the new evidence [6].

There are cases in which medical interventions are necessary, however this is not the rule. The medicalization of the female body, which treats pregnancy as a disease, is one of the most powerful sources of the sexist ideology of our culture. This profound distortion in Brazilian medical practice is determined by multiple historical, structural and cyclical factors, which directly affect the way society in general, and medicine in particular, regard women [7].

Nevertheless, women are harmed by the administration and infrastructure of public services, where primary operating conditions are often lacking, such as the adequate number of available beds. Meanwhile, $70 \%$ of the Brazilian population, which depends on our Public Health System (SUS) for conception, is unable to assert their rights [8].

Thus, there is a violation of the human and reproductive rights of women, including the violation of the rights to equality, non-discrimination, information, integrity, health, and reproductive autonomy. Recently, the term "obstetric violence" has been used to indicate these events. Therefore, it is imperative, through the approach of this theme, to critically discuss childbirth assistance, contextualizing gender, cultural, structural, scientific issues (Evidence-Based Medicine), in order to guarantee the protection and empowerment of women about violations of sexual and reproductive rights. Given this, this study aimed to: gather and review the concepts and conduct related to humanized childbirth in various sources of literature on the topic addressed; contextualize unnecessary interventions in childbirth through the concept of obstetric violence; describe the political situation of humanization of childbirth in Brazil; elucidate concepts about humanization; consider transdisciplinarity and horizontalization in 
Fernanda Cessel Marques, João Vítor Mendes Vilela, Emanoel Nascimento Costa, Kenne Samara Andrade, Nayra Carla de Melo, Eduardo J.S. Honorato, and e Sônia Maria Lemos

childbirth care; contextualize the adhesion of health professionals to humanization; correlating obstetric conducts to scientific evidence, and incite the need to rectify the person's role in the delivery process.

\section{METHODOLOGY}

It is a literary review, carried out by searching the terms "humanized delivery," "assistance to labor," "cegonha network"(Brazilian network) and correspondents in English and Spanish on the platforms PubMed, UptoDate, LILACS, Cochrane Library and Google Scholar, in addition to the use of printed literature from official publications, manuals and guidelines of the Brazilian Ministry of Health. For specific conducts, terms such as "pelvic floor strength", "episiotomy", "amniotomy", "obstetric violence" and "Doula". We used publications since 1990 as a search filter in order to elucidate the humanization in force at the time, until the year 2019.

The articles' initial selection was carried out based on their titles and, when related to the subject, the full text of several areas of science such as medicine, psychology, nursing, anthropology, speech therapy, and philosophy. As for the conduct used in care, randomized clinical trials, and specific systematic reviews for a recommendation were initially used. In the absence of clinical trials and meta-analyses, observational studies were selected and, if they were nonexistent, the recommendations of the assistance guidelines and protocols of medical societies of the obstetric specialty such as the Brazilian Federation of Gynecology and Obstetrics Associations (FEBRASGO) or the World Health Organization (WHO) were used. Also, doctrines, articles, jurisprudence, and other materials that discuss the topic were used.

Two hundred fifty-nine articles were found, and, of these, 67 were selected for the present review. This work discusses the problem of the routine use of episiotomy and amniotomy, which are still frequent in Brazilian maternity hospitals. Besides, the pelvic floor strength in the postpartum period is also discussed according to the chosen way of delivery.

\section{RESULTS AND DISCUSSION}

\subsection{OBSTETRIC VIOLENCE: INSTITUTIONALIZED AND SYMBOLIC}

From the discussions about unnecessary interventions in childbirth care, the concept of obstetric violence emerged, conceptualized in 2014 by a Brazilian bill No. 7,633 / 142, by then deputy Jean Wyllys [9]:

"Art. 13 - Obstetric violence is characterized as the appropriation of the body and reproductive processes of women by health professionals, through dehumanized treatment, abuse of medicalization and pathologization of natural processes, which causes the loss of autonomy and capacity of women to decide freely about their bodies and their sexuality, negatively impacting women's quality of life. Single paragraph. For the purposes of this Law, obstetric violence is considered to be any act practiced by a health team professional that verbally or physically offends pregnant women in labor, in an abortion situation and in the postpartum period / puerperium".

According to the World Health Organization [10], obstetric violence is characterized as "abuse, disrespect, mistreatment, and neglect during childbirth care in health institutions." This is understood as any procedure practiced by a member of the medical care team (not only the obstetrician, but also the nurse, the anesthetist, the nursing technician, the maternity receptionist, among others), which occurred during pregnancy, childbirth, birth, postpartum period and abortion, which not only violates women's rights to respectful care but also threatens the right to life, health, physical integrity, and non-discrimination [9].

Thus, obstetric violence characterizes acts such as violence exercised with screams; painful procedures without consent or information, and lack of analgesia and neglect; the refusal of admission to the hospital (Brazilian Law 11,634 / 2007); companion entry impediment (Brazilian Law 11.108 / 2005); psychological violence (aggressive, discriminatory, rude, mocking treatment, including because of their color, ethnicity, race, religion, marital status, sexual orientation and number of children); impediment of contact with the baby; the impediment to breastfeeding; cesarean section without adequate indication and consent; conducting episiotomy indiscriminately; the use of oxytocin without the woman's consent; Kristeller's maneuver (pressure on the pregnant woman's belly to push the baby); the prohibition or neglect of food or hydration, in addition to the impositions of health professionals regarding the positions adopted during labor. 
A survey of 2,365 women from all over Brazil showed that 1 in 4 women is recognized as a victim of abuse during childbirth [11]. This rate would undoubtedly be higher if women were aware that the term is much broader. The biomedical assistance model often practices almost silent violence, which does not use physical force, is challenging to be recognized as such and which Pierre Bourdieu called "symbolic violence". It is manifested through the acceptance of shared rules and beliefs as if they were "natural" and the critical inability to recognize the arbitrary character of such rules imposed by the dominant authorities in a field (cultural, economic, educational, scientific, scientific, journalistic) [12].

In the context of childbirth, social coercion occurs mainly in the fields of culture, economics, and health, which naturalize systematic violations of the dignity of women; based on the historical-cultural construction that relegates pregnancy to the "place" of pain, suffering and submission [13].

The materialization of symbolic violence under the obstetrics is reflected in the asymmetry of the relationship between health professionals and the patient; in the erasure of identity (use of nicknames); in academicist language that escapes common understanding; coercive communication; in the absence of information provided during prenatal care; in the absence of an appropriate hospital bed; the scarcity of appropriate materials and medicines; little communication; the problematic integration of the assistance team; in discontinuing the education of these professionals; in disdain for the manifestations of pain; among other situations [13].

Many of these situations have become so natural that some women consider this institutionalized violence to be routine. Such a condition of ignorance removes the woman and the fetus from the place of protagonism at the time of delivery. Functions that they assign to health services and their respective teams because of their trust [13].

In a society structured around gender-based violence, health professionals' responsibility should not be only about their conduct in order to avoid legal proceedings. Silence in the face of what others do also makes them complicit in precarious childbirth assistance. The action or omission of the professional that results in damage to the client can be characterized as intentional, that is, with a desire and prediction of a harmful result, characterizing the intent or without intention, in the criminal cases. In any case, the professional respond ethically, civilly and criminally for the damages that his conduct entails, such as harmful acts against life, bodily injuries, life and health hazards, mistreatment and abandonment of the disabled [13].

\subsection{THE HUMANIZED PUBLIC POLICY IN BRAZIL}

Public policies in childbirth care have been discussed in recent decades by different professional spheres to consolidate the humanized care system for these clients during prenatal, delivery, and puerperium. Since 1985, discussions about humanization in the scope of obstetrics have become evident, and with this, public policies have been instituted to attempt to comply with this type of care.

In 1999, the Brazilian Ministry of Health implemented the Centro de Parto Normal (CPN - Normal Labour Center), defined as a health unit that provides humanized and quality care exclusively for normal childbirth without dystocia, aimed at assisting the normal risk childbirth, belonging to a hospital establishment, located in its internal or external facilities. It aims to adapt space by promoting the development of physiological mechanisms for childbirth and labor, welcoming pregnant women, and conducting childbirth care without dystocia by the obstetrician nurse who guarantees women and children's rights.

Based on the humanization of care, in 2002 the Brazilian government launched The Humanization Program for Prenatal and Birth instituted by the Ministry of Health (PHPN) through Ordinance / GM No. 569, of 6/1/2000, whose primary objective is to ensure the improvement of access, coverage, and quality of prenatal care, childbirth and postpartum assistance to pregnant women and newborns, from the perspective of citizenship rights [14].

The PHPN is based on the precepts that the humanization of obstetric and neonatal care is a primary condition for the adequate monitoring of childbirth and the puerperium. Notwithstanding, humanization took place through the imposition of government policy, in order to reduce the rate of cesarean sections performed in the country (38.6 per 100 births in 2006), which was well above that recommended by WHO (15 to every 100 deliveries) [15].

Changes in humanization occurred discreetly since initially; the biggest concern was the reduction of maternal and neonatal morbidity and mortality indicators. Little was discussed about a qualification that placed women as protagonists in childbirth [15].

In 2005, Brazilian LAW No. 11,108 determined that the parturient woman had the right to a companion during the entire process that involved the delivery. In 2011 the Ministry of Health established, by decree No. 1,459, the 
Fernanda Cessel Marques, João Vítor Mendes Vilela, Emanoel Nascimento Costa, Kenne Samara Andrade, Nayra Carla de Melo, Eduardo J.S. Honorato, and e Sônia Maria Lemos

Rede Cegonha (RC), which is a strategy of the Ministry of Health to qualify the attention to adult women, young people and adolescents for reproductive planning, prenatal care, childbirth and birth, abortion, puerperium, and children up to 2 years old, expanding access, strengthening networking and changing care practices. It is continuously proposed to implement a Model of Attention to Childbirth and Birth based on scientific evidence and the principles of humanization. Besides, investments were included for the construction/reform of ANCs in the SUS, training professionals, and implementing committees and councils to monitor the network, among others [15].

In addition to the CPNs, there is the Casa da Gestante, Bebê e Puérpera (CGBP), a care unit for this group belonging to high-risk maternity. It has the main objective to ensure assistance to pregnant women, newborns, and postpartum women in intermediate care between the home and the reference hospital, contributing to more appropriate care to the situation that requires surveillance and proximity to the reference services, although not there is a need for hospitalization [16]:

"The CGBP aims to provide users: hosting; monitoring by nurses and nursing technicians twenty-four hours a day and seven days a week; daily care of the multidisciplinary team of the reference hospital; and access to health care by the referral hospital during the stay. Thus, it aims to ensure the permanence of pregnant women and women at risk who require constant surveillance in a non-hospital environment and / or cannot return home, mothers who have babies admitted to the ICU / ICU and babies in nutritional recovery who require monitoring by the reference team high risk, but that do not need the hospital environment (third phase of the kangaroo method)" [17].

In the state of São Paulo, Law No. 15,759, of March 25, 2015, guaranteed the right of all pregnant women to have a Humanized Childbirth in public establishments, which guaranteed women rights such as the option of elective procedures that safeguarded the safety of the child. It provides greater comfort and well-being, including medical procedures for pain relief, adopts only routines and procedures the extent and content of which have been the object of scientific review and evaluation by the WHO [17].

In São Paulo since 2016, it is predicted by the Federal Public Ministry and the State Secretariat of Health that maternity hospitals send quarterly reports on planned goals regarding childbirth assistance policies, with the risk of losing the respective financial transfers according to indicator reports. For the time being, goals for episiotomy and oxytocin are not yet foreseen, but it is stated that the rates of these procedures must be informed. Escort rates, skin-to-skin contact, and risk classification are also analyzed. Good childbirth practices should also be included in the analyzes, although this does not have a specific indicator in Rede Cegonha. Also, the Health Department conducts visits to the maternity hospitals to monitor the Cegonha Network in the city of São Paulo, to analyze the results obtained in the visits and subsequently carry out an action plan for improving care [17].

However, this reality is peculiar, like many regions of the country still have difficulties in the elaboration and inspection of the norms aimed at humanized assistance to childbirth.

\subsection{HUMANIZED CHILDBIRTH: AN EXPRESSION STILL NEEDED}

During the 19th and 20th centuries, many technological advances began to be applied in the health area, at all levels of care. Associated with the technological development that is experienced in this period, biological processes, as well as pregnancy, are commonly interpreted by the biomedical conception. This model simplifies complex phenomena and the cause-effect relationship; that is, a Cartesian distinction is made between mind and body, an analysis of the body as a machine, minimizing social, psychological, and behavioral aspects [18].

Although technological innovations are associated with the progress of science and the degree of modernization of society, in the field of health, this reasoning can generate an equivocal social and economic devaluation of practices perceived as having less technical and technological complexity.

In this sense, the concept of humanization occupies a prominent place in the current proposals for the reconstruction of health practices in Brazil to guarantee its greater comprehensiveness, effectiveness, and access [19]. Although much has already been done in terms of discussing and restructuring technologies and planning services, there is still some resistance or prejudice in the area of midwifery. It is said by some professionals that there is no "animalized delivery," and therefore, it would not make sense to term it as "humanized."

Childbirth in our species will always be a human event; however, the proposal is to humanize the assistance of this process encompasses according to MS [20]:

"The appreciation of the different subjects involved in the health production process: users, workers, and managers. To improve the autonomy and protagonism of the subjects and groups involved in the health process,

International Journal of Research -GRANTHAALAYAH 
aiming at increasing the degree of co-responsibility, the participation of workers in decision-making processes, and establishing solidary bonds in the production of networked health (National Humanization Policy)".

The theme related to the humanization of health care is relevant in the context of childbirth as well. Attention and care for pregnant women should be based on principles such as comprehensive care, equity, and social participation of the user, demanding the review of daily practices with an emphasis on creating less alienating workspaces that value dignity worker and users [21].

Childbirth is not just a physical event. It is a biopsychosocial and even spiritual process for those who believe. It takes a careful look at the part of the whole team and institution so that the assistance is transdisciplinary, solidified by Evidence-Based Medicine (EBM) [21].

Therefore, the concept of humanization of childbirth can be quite diverse. There is the movement defending it as a process that respects the individuality of women, valuing it as a protagonist and allowing the adequacy of assistance to the culture, beliefs, values, and diversity of opinions of these people [22]. Likewise, the term humanization was attributed by the Brazilian Minister of Health and his technical team to the Prenatal and Birth Program to improve the conditions of care [23].

\subsection{TRANSDISCIPLINARITY AND HORIZONTALIZATION IN CHILDBIRTH CARE}

The obstetrician is the professional who graduates from the Obstetrics course - São Paulo University offers the only one in Brazil. They perform low-risk deliveries and prenatal care. The differential of the profession is to conduct the moment of delivery in an even more humanized way. The nurse with a specialization in Obstetrics (graduated in Nursing and post-graduated in Obstetrics) is called an obstetric nurse. This professional works in prenatal and lowrisk births. Its differential concerning the obstetrician is that, because his graduation is broader, the nurse can act in several areas, such as ICU, Emergency Room, Pediatrics, and others. On the other hand, the obstetrician is a professional who has a degree in Medicine and completes a residency in Gynecology and Obstetrics. The obstetrician doctor monitors prenatal care, diagnoses pathologies, assists low and high-risk births, monitors births, and performs cesarean sectionscesarianas [24].

\subsubsection{DOULAS}

The Greek term doula comes from maieutics, a form of female assistance to childbirth in classical antiquity, of a ritualistic character, but incorporating a relative specialization of technical roles. Their role is different from the midwife, as she does not deal with childbirth assistance, but with the parturient, including emotional encouragement, help walking and changing positions, breathing, bathing, starting breastfeeding in the delivery room, among others. In some contexts, the doula plays an essential role in the puerperium and in supporting lactationlactação [25].

According to the Brazilian Ministry of Health, the trained companion, in addition to emotional support, must provide information to the parturient about the entire course of labor and delivery, interventions and necessary procedures, so that the woman can participate in the decisions. During labor and delivery, the companion can contribute: Instructing the woman to assume the position that most pleases her during contractions; Favoring the maintenance of a peaceful and welcoming environment, with silence and privacy; Assisting in the use of breathing techniques, massage, and warm baths; Guiding the woman on pain relief methods; Encouraging the participation of the husband, partner, or another companion of the woman's free choice in the whole process; Supporting and guiding women throughout the expulsion period, including the possibility of freedom of choice as to the position to be adopted [26].

However, the professional doula still finds high resistance from medical professionals, despite scientific evidence demonstrating that support by doulas has reduced the duration of labor, reduced the number of cesareans and unnecessary interventions [27], [28].

A Cochrane meta-analysis of 22 randomized clinical trials, with a total number of 15,288 parturients, showed that pregnant women who received continuous support during labor had a shorter duration of labor and a higher probability of spontaneous vaginal delivery (RR 1.08 with 95\% CI ), with reduced need for analgesia (RR 0.90 with 95\% CI), less chance of cesarean section (RR 0.78 with 95\% CI) and less need for instrumentation of vaginal delivery (RR 0.90 with $95 \%$ CI). The study also showed a significant decrease in negative experience concerning childbirth 
Fernanda Cessel Marques, João Vítor Mendes Vilela, Emanoel Nascimento Costa, Kenne Samara Andrade, Nayra Carla de Melo, Eduardo J.S. Honorato, and e Sônia Maria Lemos

(RR 0.69 with 95\% CI) and less probability of the newborn (NB) having a low Apgar score in the fifth minute of life (RR 0.69 with 95\% CI) [29].

\subsubsection{OBSTETRIC NURSES}

The role of the assisting nurse and the obstetric nurse in Humanized Childbirth is different. The role of the obstetric nurse in labor is based on the Cofen's Resolutions Cofen n. 223/1999 and 439/2012, and is responsible for assisting the pregnant woman, the parturient and the puerperal woman, including the evolution and labor, delivery and obstetric assistance in emergency situations and also for normal delivery, identifying obstetric dystocia and taking measures until the arrival of the doctor [30].

Under an ideal minimal state context, the work of these professionals in Brazil has been encouraged by national health policies. The support for obstetric nursing by the Brazilian Ministry of Health can be demonstrated by Ordinance No. 163 of September 22, 1998 [31] which, among other duties, gives nurses the possibility of issuing an admission report and the inclusion of this professional in the Brazilian Health System (SUS). Another example is Ordinance No. 985 of August 1999 [32] that created the Centro de Parto Normal (CPN) defining the obstetric nurse as a necessary member of the team. More recently, in 2009, Ordinance No. 11633 regulated the issuance of Birth Certificates by health professionals in home births, ceasing to be an exclusive activity of doctors, expanding to obstetric nurses, midwives, and traditional midwives, which indicates, even if subliminally, the recognition and appreciation of births performed by nurses at home.

Furthermore, one of the factors that contribute to the provision of ethical and safe nursing care is the nurse's knowledge of the legal aspects, rights, and obligations implicit in the professional practice itself, since it can influence decision-making [34].

\subsubsection{THE NURSES ARE RESPONSIBLE FOR THEIR ACTIONS}

As nurses conquer spaces and seek to autonomously assume their duties, following technological advances and progress in health sciences, doubts are raised about professional responsibility in its legal aspects. Currently, nurses' civil liability is regulated by the Brazilian Civil Code, the Federal Constitution, and the Consumer Protection Code (CDC), which require reparation through indemnity for the losses caused by the error in professional assistance ${ }^{13}$.

In addition to civil liability, the nurse may be held criminally liable, in the face of conduct predicted to be contrary to the current criminal law. Conducts considered offenses constitute a danger of injury to an individual or collective legal and criminal asset and, more broadly, an attack on a value established as fundamental to the human and cultural perpetuity of a group [35].

Therefore, the nurse who commits a professional error can be held responsible in the civil and criminal sphere, for the same situation. However, in criminal liability, the sanction is imposed on behalf of the entire community, due to the aggression against social peace, whereas in civil liability, the damage caused directly to the person involved is observed [36].

\subsubsection{THE MINIMUM STATE IN THE CONTEXT OF THE INSERTION OF OBSTETRIC NURSES IN CARE}

A large number of obstetric doctors still consider that obstetric nurses invade their workspace, moving the parturient from the operating room to the delivery room and receiving the SUS payment that would be due to them. It is, therefore, a corporate and financial dispute, with reactions from both parties [30].

The argument to refute these official measures was based on medical security and the impoverishment of medicine [37].

The first argument is based on the concept of risk implicit in the medicalization of childbirth to demarcate it as a medical act and in the representation of technological childbirth as modernity and progress in obstetric care. The second argument refers to these measures as aimed at the most impoverished population and the reduction of maternal and child care costs, which puts pregnant women at risk and is advertised as humanization measures for childbirth [37]. 
In these arguments, the State appears as a promoter of differentiation strategies in the quality and access of services through cost rationalization and technological simplification of public health actions, constituting a segmentation between the central and peripheral areas of the city in the distribution and provision of resources and professionals [37].

In this way, humanized childbirth care practices, performed by obstetric nurses, can have different interpretations, such as advancing towards respect for the uniqueness and subjectivity of women. Besides, it values the necessary quality of obstetric care, or as an anachronism of politics of health that uses the discourse of humanization as a background to reduce the costs involved with the increasing technological complexity in health, including the professional nurse whose work has less social and economic representation compared to that of the doctor [37].

When investing in childbirth care by the obstetric nurse, the neoliberal government follows its ideal of a minimal state, considering that this specialist's professional practice involves light and low-cost technologies. The wage issue is also added, as a female profession related to care, the remuneration of nurses is lower, which reduces public spending and enables the continuation of neoliberal reforms.

\subsection{PROFESSIONALS' DIFFICULTIES REGARDING HUMANIZATION}

The campaign of Humanization of health currently stands out in any new health care project. Thus, to refute today, the need to humanize Medicine, health systems, hospital assistance, and even medical education seems inconceivable. However, curiously, the objective, which is a universal consensus, does not seem to be achieved, and, in practice, everything is more complicated than it initially seems [38].

Since its effectiveness is not made as a general and abstract proposal, Humanization cannot be taken only as a principle, but also as public policy. As for the proposition of the humanization policy for childbirth, it is necessary not to confuse it with the Unified Health System (SUS) principles, which would make it broad, generic, and outside the experience's singularities. Another issue that must raise concerns is related to health workers [19].

It is necessary to wonder on whether they are in a position to guarantee a humanized service, considering that, almost always, they are subjected to mechanized work processes that limit them in the possibility of becoming more critical and sensitive people, as well as being fragile in the continuous coexistence with pain, suffering, death, and misery [19].

The most practical way to perceive the need for Humanization of health is to observe the consequences of its absence. When there is a clamor for the Humanization of a situation, of an attitude or profession, it is because in some way something is claimed that is understood as essential in a given concrete circumstance [38].

Once placed in the care position, the need to be well physically and mentally is inseparable, as others depend on sensitivity for adequate care. Commonly, doctors work 60 hours or more per week, with 24-hour shifts of continuous work. At the end of these shifts, recent studies show that these doctors show loss of concentration and emotional weakness [39]. Exhaustive routines like this promote the development of Burnout syndrome. This syndrome characterized by fatigue, depression, irritation, and inflexibility is present worldwide in 1 in every two doctors in the world [40], [41].

A meta-analysis from the University of Manchester comprising 42473 doctors adds that doctors with Burnout syndrome expose patients to twice the risk of suffering an incident in healthcare, as they are more likely to fail in fundamental aspects of professionalism such as adherence to guidelines of treatment, prescription of exams and discharge, deficiency in the ability to communicate and put themselves in the patient's position. The lack of connection with the patient, caused by emotional exhaustion, was the factor that had the most reliable connections with these results [42].

We should also consider that one of the explanations for a large number of errors observed in medical practice, in general, is precisely the absence of mechanisms that reduce their occurrence, or that intercept the error before reaching the final consumer (the patient). In other words, it works with the premise that the health professional does not make mistakes and, therefore, mechanisms for prevention and correction are not created [43].

In this sense, investing in organizational strategies to monitor and improve the doctor's well-being and patient care results is a way to decrease the frequency of errors in medical techniques and procedures. The creation of rules and procedures routines would prevent, for example, professionals working more than 24 hours in a row [43]. Health professionals must be concerned with seeking assistance for their own care before offering it to clients. 
Fernanda Cessel Marques, João Vítor Mendes Vilela, Emanoel Nascimento Costa, Kenne Samara Andrade, Nayra Carla de Melo, Eduardo J.S. Honorato, and e Sônia Maria Lemos

\subsubsection{COMPLEXITY OF HUMANISTIC TRAINING}

Concerning the proposition of humanization as health policy, it is also necessary to consider the training, from graduation and specialization, of professionals who make health services work daily. The medical culture in which undergraduate students are socialized is characterized by an ideology that rectifies, dissociates, and juxtaposes two dimensions [44].

A dimension called "competence" refers to technical and scientific knowledge and is expressed in the language of the basic sciences in which knowledge, skills, and techniques are portrayed as worthless facts; the other, "care", refers to the intersubjective dimension, that is, to the interactions between the subjects concerning the care act, which is expressed in the language of values, attitudes, and emotions [44].

These distinct dimensions also present an unequal valuation. Not only in teaching but also the exercise of medical work, since technical, scientific performance is prioritized, while the intersubjective dimension tends to be treated as a secondary aspect of work and socialization in medicine [44].

Besides, socialization in medicine exposes the student to divergent and sometimes conflicting concepts, values , and practices, given that the perspectives of their teachers, the "lines" of work, and the "schools" of thought are heterogeneous, with conflicts within the disciplines. However, there is rarely the possibility of dialogue itself; students "must respect" and practice the teacher's opinion, as this can often impair their assessment ${ }^{45}$.

However, different teaching-learning models can be used, in order to stimulate dialogue and praxis in the learning environment. By contrasting the ways of equating experience and scientific knowledge in clinical judgment, it contributes to the construction of professional autonomy as a value [45].

These contrasts lead to a variable relevance attributed to the notion of humanization of childbirth. An indication of this variability is expressed in the contents contained in the disciplinary set offered by the Departments of Obstetrics and Gynecology to students from four renowned medical schools in the State of São Paulo and in the teaching materials offered in medical residency programs. They all make some reference to the term "humanization." However, the value attributed as thematic in teaching seems to be quite diverse: from the absolute lack of mention in the mandatory subjects to the use of the term in the declaration of the teaching mission of the faculty, in the course subjects and / or the presence of technical manuals from the Brazilian Ministry of Health in the recommended bibliographies [46].

It should be noted that these manuals systematize scientific evidence, incorporate some WHO guidelines based on evidence-based medicine (EBM), in addition to being produced in a partnership or with the technical support of the Brazilian Federation of Obstetrics Gynecology (Febrasgo), among other entities. However, the dissemination in medical schools is still quite variable, despite being distributed to all its affiliates under the Humanization Program in Prenatal and Birth [46].

\subsection{MALPRACTICES AND THE ROLE OF WOMEN IN CHILDBIRTH}

The legal repercussions of the acts are not often disclosed and discussed during academic training and, consequently, in the daily practice of care. What is disseminated is the idea that the doctor, especially in obstetric training, must take care of the judicialization of his acts. The medical error can be a consequence of a series of situations, but there is no doubt that establishing a good doctor-patient relationship based on respect for the person, could prevent its occurrence and most legal processes. The way to avoid unsafe situations and the increase in the occurrence of medical errors in obstetrics can be the realization of an empathic relationship, which allows trust between doctors and pregnant women and their families and professional staff [47].

Saying that "the client does not have the capacity to participate in decision-making on conduct" denotes the deficiency in the relationship ${ }^{47}$. Adequate communication must be established, with accessible language that substantially enables the client to participate in decisions about her body and the labor process of childbirth.

It is up to the doctor to respect and consider their patient, regardless of whether there is an error. The doctor who is conducting the care is at risk. However, the illusion of omnipotence can cause the denial of the perception of an adverse clinical condition [47].

The fact of making the decision a less individualized character in the doctor and more autonomous for the patient, during the pre/trans / postpartum period, causes the professional to know how to deal with something 
Humanized Childbirth: A Transdiciplinary Review

unexpected, since the patient may refuse to perform a specific procedure, different from that suggested by the doctor [47].

The increase in the number of cases judicialized as medical errors in recent years can be understood as a consequence of the problematic situation of the health service in the country. The information is more and more accessible. However, the physician is still resistant to horizontalizing the decision making not only with the client but also with the other health professionals who can compose the childbirth care team.

Besides, there is great difficulty in assuming the error, which prevents awareness of existing problems and the possibility of studying ways to avoid them. In Brazil, the error still needs to be seen as a fact intrinsic to the medical reality, so that its form of acceptance, treatment, and conduct have less weight and guilt, and thus can be further discussed. Errors will always happen, but minimizing them requires, first, the acceptance of their existence [47].

\subsection{CONDUCT AND EVIDENCE}

Humanization focuses on qualifying care, involving concerns, on the one hand, with the respect and promotion of the human rights of women receiving assistance. On the other, with training or education of professionals, in addition to physical facilities and technological resources available, as well as a theoretical basis through scientific evidence-based medicine (EBM) that should guide care routines. Thus, in some studies [48], after a critical assessment of the evidence from scientific research, the next steps should be: "combine the evidence from different sources; consider its validity, importance, and applicability; make a decision on the clinical question initially formulated, based on the best available evidence".

Supporting practices in medicine, mainly in obstetrics, based on the best evidence from rigorous methodologies that give them comparative validity, is a civilizing process. Few attitudes can bring more efficiency and avoid suffering and waste of money and lives than the use of evidence for decision making, both in human health and in the right to health, in education, in agriculture, in veterinary medicine, and social science. It is necessary not to deviate from this civilizing trajectory. To recommend treatments that have no scientific basis is equivalent to going back to 1650 [49].

Because of this, in order to minimize inappropriate and unnecessary childbirth practices, the WHO published, in 1996, the Guide to Care in Normal Birth: a Practical Guide, a reference for the implementation of humanized childbirth in health services, and recommended practices obstetric, based on scientific evidence, classifying them into four categories: useful practices that should be encouraged; harmful or ineffective practices that must be eliminated; practices with insufficient evidence and that should be used with caution; and practices that are often misused, causing more risk than benefits [50].

Among the practices to be encouraged is the partogram, the supply of fluids orally during labor, non-invasive methods for pain relief, freedom of position and movement of women in labor, skin contact a skin between mother and child, and breastfeeding in the first hour of life. Among the ineffective or harmful practices in conducting normal childbirth and that need to be discouraged are the use of the enema, the trichotomy, the routine prophylactic catheterization, the Valsalva maneuver during the second stage of labor, the early amniotomy and routine, frequent vaginal exams, routine use of episiotomy, early clamping of the umbilical cord, routine use of oxytocin and forced traction of the umbilical cord in the third stage of labor, among others [50], [51].

\subsubsection{PELVIC FLOOR PROTECTION: VAGINAL DELIVERY VS. CESAREAN SECTION}

Pregnancy and childbirth influence the pelvic floor musculature, which can decrease its tone and lead to a set of problems called pelvic floor dysfunctions, such as urinary incontinence and dyspareunia, among other conditions that can be transient or permanent [52], [53].

These problems can negatively affect a woman's sexual, physical, and professional activities. The question is about the exposure or protection under these morbidities that natural childbirth, so stimulated by the humanized childbirth movement, could exercise [54].

A Brazilian study conducted in 2016 with 96 women compared the pelvic floor muscle strength in primiparous women in the normal postpartum and cesarean section, relating it to sociodemographics, nutritional status, and urinary incontinence, dyspareunia, perineal exercise during pregnancy, perineal condition and weight of the newborn. PeritronTM 9301 was used to analyze muscle strength between 50 and 70 days postpartum, with 24 
Fernanda Cessel Marques, João Vítor Mendes Vilela, Emanoel Nascimento Costa, Kenne Samara Andrade, Nayra Carla de Melo, Eduardo J.S. Honorato, and e Sônia Maria Lemos

primiparous women undergoing cesarean section and 72 during normal delivery. Muscle strength averages between groups were compared by Analysis of Variance to two factors, and as a result, the pelvic floor muscle strength was $24.0 \mathrm{cmH} 20( \pm 16.2)$ and $25.4 \mathrm{cmH} 2 \mathrm{O}( \pm 14.7)$ in normal postpartum and cesarean deliveries, respectively, with no significant difference. Muscle strength was shown to be greater in normal postpartum women with $\geq 12$ years of study ( $42.0 \pm 26.3$ versus $14.6 \pm 7.7 \mathrm{cmH} 20 ; \mathrm{p}=0.036)$ and who underwent perineal exercise $(42.6 \pm 25.4$ versus $11.8 \pm 4.9 \mathrm{cmH} 20 ; \mathrm{p}=0.010$ ), compared to cesarean sections. There was no difference in muscle strength according to the type of delivery regarding nutritional status, urinary incontinence, dyspareunia, perineal condition, and newborn weight [54].

Consequently, although further studies are needed to assess the pelvic floor in the postpartum and the different birth pathways, the current scientific evidence strongly suggests that the muscular strength of the pelvic floor does not differ between primiparous women in terms of the type of delivery and that women in normal postpartum who performed perineal exercise during pregnancy, they did not experience loss of perineal muscle strength. Therefore, to protect women from pelvic floor comorbidities, it is not appropriate to determine a mode of delivery in advance, but rather to encourage them to exercise preventively [54].

\subsubsection{EPISIOTOMY}

An episiotomy is one of the most common surgical procedures in obstetrics. However, it is one of the only ones that is still performed without any specific consent from the patient or in a coercive way, despite the shared decision being recommended in the obstetric manuals and guidelines. Its practice was introduced over 250 years ago without scientific evidence to support its benefit [55]. The suggestion of an incision in the perineal body to help facilitate the exit of the newborn in complicated vaginal deliveries; however, it has now been systematically recommended for all vaginal deliveries.

The suggestion of an incision in the perineal body to help facilitate the exit of the newborn in complicated vaginal deliveries; however, it has now been systematically recommended for all vaginal deliveries. Between 1915 and 1925 , Episiotomy took the context of prophylaxis. Thus, it became justified to avoid perineal traumas and prevent child morbidity and mortality and gynecological problems, such as rectocele, cystocele, and pelvic muscle relaxation [56].

The World Health Organization (WHO) recommends an episiotomy rate of $10 \%$. However, over the years, this intervention has been widely practiced in Brazil. Thus, a national demographic survey of child and women's health revealed a 71.6\% episiotomy rate in Brazil and a 78.5\% rate in the state of Rio Grande do Sul [57].

This procedure has recently been challenged both by the humanized childbirth movement and by the scientific community. A study carried out at the University of Pennsylvania has raised questions about the lower biomechanical properties of scar tissue after trauma, compared to uninjured tissue. It led to the questioning that there is no proven benefit for Episiotomy, suggesting that this procedure may result in tissue weakening and the susceptibility to injuries at subsequent delivery. This same cohort used a sample of approximately 2600 women who had their first and second deliveries at the same hospital over ten years and demonstrated that the Episiotomy in the first delivery was not protective against third or fourth-degree lacerations. Thus, this high rate of Episiotomy in the first delivery is the only factor responsible for increasing the risk of significant laceration in the second delivery for up to $40 \%$ of women [58].

A study carried out in an obstetric care service located in the city of Recife, was the first randomized clinical trial in Brazil to compare the selective use of Episiotomy in 122 women with a protocol of not performing an episiotomy with 115 women, classifying their results as an original contribution to current literature. The methodology employed in the study was sufficient to show any possible benefits or detrimental effects in either of the two groups. An overall episiotomy rate of less than $2 \%$ was found in the two groups evaluated in the present study, showing that it is possible to implement a non-episiotomy protocol for a group of women with term pregnancies and fetuses in the cephalic position without any statistically significant differences in regarding the selective practice of the procedure [59].

Some authors have also concluded that imminent laceration is not an indication for Episiotomy, as it does not bring any demonstrable benefit to the mother or fetus. The supposed benefits proposed to the fetus with Episiotomy include cranial protection, especially for preterm infants, reduced perinatal asphyxia, better Apgar scores, lower fetal acidosis, and reduced complications in shoulder dystocia [58]. 
In Evaluating outcomes in the third month after delivery, it is observed that in the presence of intact perineum or spontaneous first and second-degree lacerations, there is no significant difference in the pelvic floor's function concerning the incidence of urinary incontinence, fecal incontinence or genital prolapse. However, when assessing the presence of dyspareunia and perineal pain, Episiotomy is related to a higher number of events (frequency of dyspareunia of $7.9 \%$ versus $3.4 \%$ with an intact perineum, and perineal pain of $6.7 \%$ versus $2.3 \%$, respectively) [60].

However, further studies should be conducted, particularly in institutions and regions where episiotomy rates remain high (although under the concept of "selective" use), in an attempt to determine whether there is any indication for Episiotomy in modern obstetrics.

\subsubsection{AMNIOTOMY}

Amniotomy, an artificial rupture of the amniotic membranes to accelerate labor progress, is among the most commonly performed procedures in obstetric practice. It is indicated in the induction of labor and preferably associated with oxytocin, but it is commonly practiced daily to reduce the length of the dilation period [61].

Among the complications of performing this procedure, pain, bleeding, infections are observed, serious complications are uncommon. However, there is an incidence of fetal distress in babies undergoing amniotomy, due to the reduction of amniotic fluid and, thus, , the compression of the umbilical cord [62].

Embora existam evidências de que a amniotomia precoce possa reduzir a duração do trabalho de parto em 60 a 120 minutos, efeitos indesejáveis podem ocorrer com essa prática, como o incremento de desacelerações precoces da Frequência Cardíaca Fetal e alterações plásticas sobre o pólo cefálico (bossa serossanguínea). Existe também um risco aumentado de infecção ovular e puerperal quanto maior for a duração do trabalho de parto com membranas rotas [26].

Although there is evidence that early amniotomy can reduce the duration of labor by 60 to 120 minutes, undesirable effects can occur with this practice, such as the increase in early decelerations of Fetal Heart Rate and plastic changes on the cephalic pole. There is also an increased risk of ovular and puerperal infection, the longer the duration of labor with broken membranes [26].

Thus, the artificial rupture of the bag must be routinely avoided, reserving its use for those conditions where its practice is beneficial, as is the case with some functional dystocia [26]. It is essential to clarify that amniotomy is not a mandatory procedure when performing labor analgesia

\section{CONCLUSION}

This literature review's approach is focused on the multiple meanings of the humanization process of childbirth care. Among them is the political legitimacy of the claim and defense of women's rights that seeks to empower the protagonists of childbirth about what is obstetric, institutionalized, or sanitary violence, as well as informing them about the possibility of a decent birth so that they can question, protect themselves and even demand their rights from the State. In this sense, there is a need for more comprehensive protective legislation, including at the federal level, which criminalizes, curbs, and, who knows, putting an end to the violence, throughout the national territory.

It is known that the term "violence" mainly implies aggression, abuse, and insults. Therefore, the term "obstetric violence" places obstetricians in a place of disrepute. However, the discomfort generated by this name cannot be stronger than the desire to protect the female body, from oppression, violations, mutilations, and constraints during conception, childbirth, and postpartum. There is a particular advance, but each advance is certainly little. It is noteworthy that the doctor's role in preventing the violation of women's rights includes the improvement of the biopsychosocial care model, promoting, in the first instance, the establishment of trust and communication that must exist between doctor and client.

In Brazil, the Ministry of Health itself rescues humanized natural childbirth, and evident progress has been achieved, as is observed in the State of São Paulo, where humanization is a reality in many maternity hospitals. However, more than a decade after implementing the National Program, care centered on the assistance model based on interventionist actions is still frequent. It may be a reflection of the difficulty of health professionals reframing their performance and conceiving the concept of humanization. 
Fernanda Cessel Marques, João Vítor Mendes Vilela, Emanoel Nascimento Costa, Kenne Samara Andrade, Nayra Carla de Melo, Eduardo J.S. Honorato, and e Sônia Maria Lemos

Through the recognition of evidence-based medicine (EBM), several techniques historically practiced have been put to the test, which was no different regarding the process of childbirth assistance, whose medicalization is questioned by recent studies. However, obstetrics is still resistant to the adoption of new proposals for humanized childbirth scientifically supported.

However, this exercise is not just in the hands of doctors or nurses, nor does it exclude the much-criticized cesarean section as a mode of delivery. Since there are absolute and relative indications for surgical delivery, as well as there are also complications in the pre-delivery that could be avoided by well-conducted prenatal care, and / or by guaranteeing medications, hospital infrastructure and adequate exams. What is proposed in the movement is the shared responsibility between trained multidisciplinary teams that guarantee everything from a dignified reception to the pregnant woman to the infrastructure and adequate administration of health services.

The professional and corporate ratifications of a resizing of powers and the rational use of resources are given in the inclusion of other trained professionals. By showing a willingness to transform their practice following the proposals defended by the humanization movement for childbirth and birth, the doulas, obstetricians, and obstetric nurses meet the demands of the productive restructuring that accompanies the Brazilian neoliberal policy, without excluding or diminishing the importance of obstetric medical practice.

To this end, it is necessary to incorporate existing technology harmoniously with the humanistic side of design. For this, some intrinsic behaviors of professionals must be reviewed. There is an urgent need for flexibility, common sense, empathy, and ethics.

Women, the legislature, the judiciary, the ministry of health, the secretariats, doctors, nurses, psychologists, and doulas must strive to bring the discourse of the humanized birth movement closer and closer to the practice in routine care of the parturition process. Each health sector can reflect and adapt its individual and collective performance to guarantee women's role in the delivery process, always based on ethics and MBE.

In the historically established misogynist context of arduous achievements and vacant themes, watertight advances, and symbolic disputes, a transdisciplinary dialogue on the theme of humanized childbirth is relevant.

\section{SOURCES OF FUNDING}

This research received no specific grant from any funding agency in the public, commercial, or not-for-profit sectors.

\section{CONFLICT OF INTEREST}

The author have declared that no competing interests exist.

\section{ACKNOWLEDGMENT}

None.

\section{REFERENCES}

[1] Kottwitz F, Gouveia HG, Gonçalves AC. Via de parto preferida por puérperas e suas motivações. Esc. Anna Nery; 22(1): e20170013.

[2] Pinheiro BC, Bittar CML. Percepções, expectativas e conhecimentos sobre o parto normal: relatos de experiência de parturientes e dos profissionais de saúde. Aletheia. Publicado em 2012.

[3] Vinaver N. Nós, mulheres, estamos desenhadas para engravidar e parir sem nenhuma dificuldade. Revista do Instituto Humanitas Unisinos. № 396 - Ano XII 2012- ISSN 1981-8769.

[4] Rocha JSS. Importância do parto humanizado na assistência hospitalar.2014 [citado 2019 Mar 16] Monografia do Curso de pós-graduação em obstetrícia e saúde da mulher, 2014 - Faculdade Santa Terezinha. São LuisMA, 2014.

[5] Santos ML. Humanização da assistência ao parto e nascimento. Um modelo teórico - monografia do curso de pós-graduação em em saúde pública, [Internet] 2002 - Universidade Federal de Santa Catarina. 
[6] Leite FMC, Mascarello KC, Almeida APSC, Fávero JL, Santos AS, Silva ICM et al. Análise da tendência da mortalidade feminina por agressão no Brasil, estados e regiões. Ciênc. saúde coletiva [Internet]. 2017 Sep [cited 2019 Mar 16]; 22(9): 2971-2978.

[7] Luz AMH. Assistência humanizada à mulher no parto: uma proposta de resgate de sua singularidade. Rev. bras. enferm. [Internet]. 2002 Feb; 55(2): 226-227.

[8] Guedes RN, Silva ATMC, Fonseca RMGS. A violência de gênero e o processo saúde-doença das mulheres. Esc. Anna Nery [Internet]. 2009; 13(3): 625-631.

[9] Mariana Beatriz B. dos Santos violência obstétrica: a violação aos direitos da parturiente e a desumanização do parto. Paper da Revista de Direito UNIFACEX, Natal-RN, v.7, n.1, 2018. ISSN: 2179-216X).

[10] WHO recommendations: intrapartum care for a positive childbirth experience. 2018. ISBN 978-92-4-1550215.

[11] FUNDAÇÃo PERSEU ABRAMO. Pesquisa Mulheres Brasileiras e Gênero nos Espaços Público e Privado. São Paulo: Fundação Perseu Abramo, 2010.

[12] Peixoto CC, Quiche LLCP. INTERSEÇÕES ENTRE A VIOLÊNCIA SIMBÓLICA E A VIOLÊNCIA OBSTÉTRICA. Anais eletrônicos do VII Seminário Corpo, Gênero e Sexualidade, do III Seminário Internacional Corpo, Gênero e Sexualidade e do III Luso-Brasileiro Educação em Sexualidade, Gênero, Saúde e Sustentabilidade/ organizadoras, Paula Regina Costa Ribeiro... [et al.] - Rio Grande: Ed. da FURG [internet] 2018; ISBN:978-857566-547-3.

[13] Rodrigues M, Branca S, Portugal MJ. A obra Trajectória histórica e legal da enfermagem. Rev. Enf. Ref. [Internet]. 2011 Mar; serIII (3): 171-174.

[14] Ministério da Saúde PORTARIA № 569, DE 1ํo DE JUNHO DE 2000 [internet].

[15] Mandarino NR, Chein MBC, Monteiro JFC, Brito LMO, Lamy ZC, Nina VJS et al. Aspectos relacionados à escolha do tipo de parto: um estudo comparativo entre uma maternidade pública e outra privada, em São Luís, Maranhão, Brasil. Cad. Saúde Pública [Internet]. 2009 July; 25(7): 1587-1596.

[16] Ministério da Saúde. Portaria no 1020/GM/MS, de 29 de maio de 2013 [internet] 2013.

[17] Ministério Público Federal, Ofício no 844, de 30 de janeiro de 2017. PR-SP 00005888/2017. Ref: IC 1.34001.007752/201381

[18] Goulart BNG, Chiari MB. Humanização das práticas do profissional de saúde: contribuições para reflexão. Ciênc. saúde coletiva [Internet]. 2010 Jan

[19] Lenz AJ, Gernhardt A, Goulart BNG, Zimmer F, Rocha, Juliana Vilanova JGR, et al. Acolhimento, Humanização e Fonoaudiologia - relato de experiência em Unidade Básica de Saúde de Novo Hamburgo (RS). Bol Saúde. 2006;20(2):59-69. [Internet]. 2006 Jan.

[20] Ministério da Saúde Política Nacional de Humanização - HumanizaSUS [Internet] 2003.

[21] Amorin M. Estudando a cesárea desnecessária: resultados do Global Survey (OMS). [Internet]. 2012 Dec [cited 2019 Mar 18].

[22] Jamile Claro de Castro, Maria José Clapis. Parto humanizado na percepção das enfermeiras obstétricas envolvidas com a assistência ao parto. Rev. Latino-Am. Enfermagem [Internet]. 2005 Dec; 13(6): 960-967.

[23] Schirmer J et al. Assistência Pré-natal: Manual técnico/equipe de elaboração: - 3a edição - Brasília: Secretaria de Políticas de Saúde - SPS/Ministério da Saúde, 2000.66p. ISBN: 85-334-0138-8 [Internet]. 2000;

[24] Loyo L. Qual a diferença entre Obstetriz, Obstetra e Enfermeiro Obstetra? [Internet]. 2016.

[25] Grilo CS. Entre a técnica e os direitos humanos: possibilidades e limites da humanização da assistência ao parto. [tese]. São Paulo: Universidade de São Paulo - Faculdade de Medicina Dissertação de Título de Doutorado - Faculdade de Medicina; 2001.

[26] Ministério da Saúde do Brasil. Secretaria de Políticos de Saúde. Área Técnica de Saúde da Mulher. Parto, aborto e puerpério: assistência humanizada à mulher/ Ministério da Saúde, Secretaria de Políticas de Saúde, Área Técnica da Mulher. - Brasília: Ministério da Saúde, 2001).

[27] Gallo RBS, Santana LS, Marcolin AC, Ferreira CH, Duarte G, Quintana SM. Recursos não-farmacológicos no trabalho de parto. Femina. 2011; 39(1):41-8. 14.

[28] Campbell DA, Lake MF, Backstrand J. A Randomized Control Trial of continuous support in labor by a Lay Doula. J Obstet Gynecol Neonatal Nurs. 2006; 35(4).

[29] Hodnett ED; GatesS; Hofmeyr GJ; Sakala C; Weston J. Continous support for women during childbirth. Cochrane Database Syst Rev. 2013 Jul 15;(7):CD003766. doi: 10.1002/14651858.CD003766.pub5. Review. In: Pubmed; PMID:23857334. [Internet] 2013. 
Fernanda Cessel Marques, João Vítor Mendes Vilela, Emanoel Nascimento Costa, Kenne Samara Andrade, Nayra Carla de Melo, Eduardo J.S. Honorato, and e Sônia Maria Lemos

[30] Silva AS, Silva LF, Lébeis MA. O parto humanizado no contexto do sistema único de saúde (sus): o enfermeiro como mediador e incentivador dessa prática. Artigo de Revisão da Faculdade Promove em Brasílica; Núcleo interdisciplinar de pesquisa; ICESP [internet] 2014.

[31] Ministério da Saúde (BR). Portaria no 163 de 22 de setembro de 1998. Dispõe sobre as das atribuições do enfermeiro obstetra e da obstetriz. Diário Oficial da União 1998 set; 1:24.

[32] Ministério da Saúde (BR). Portaria no 985 de agosto de 1999. Dispõe sobre a criação do Centro de Parto Normal-CPN, no âmbito do Sistema Único de Saúde/SUS, para o atendimento à mulher no período gravídicopuerperal. Diário Oficial da União1999 ago; 51:2.

[33] Ministério da Saúde (BR). Portaria no 116 de 11 de fevereiro de 2009. Dispõe sobre a coleta de dados, fluxo e periodicidade de envio das informações sobre óbitos e nascidos vivos para os Sistemas de Informações em Saúde sob gestão da Secretaria de Vigilância em Saúde. Diário Oficial da União, Brasília 2009 fev.

[34] Winck DR, Brüggemann OM. Responsabilidade legal do enfermeiro em obstetrícia. Rev. bras. enferm. [Internet]. 2010 June.

[35] Prado LR. Curso de direito penal brasileiro: parte geral. 8a ed. São Paulo: RT; 2008).

[36] Bucci MC. Responsabilidade civil. São Paulo: Ícone; 2003.

[37] Prata JA; Progianti JM; Pereira ALF. 0 contexto brasileiro de inserção das enfermeiras na assistência ao parto humanizado. [internet] 2012. Rev. enferm. UERJ, Rio de Janeiro, 2012 jan/mar; 20(1):105-10.

[38] Blasco PG. O humanismo médico: em busca de uma humanização sustentável da Medicina. RBM. Revista Brasileira de Medicina, v. 68, p. 12-4, 2011. [internet] 2011.

[39] Samkof JS, Jaques CHM. A review of studies concerning effects of sleep deprivation and fatigue on residents performance. Acad Med 1991; 66:687-93.

[40] Moreira HA, Souza KN, Yamaguchi MU. Síndrome de Burnout em médicos: uma revisão sistemática. Rev. bras. Saúde ocup. [Internet]. 2018.

[41] Tucunduva LTTM, Garcia AP, Prudente FVB, Centofanti G, Souza CM, Monteiro TA et al. A síndrome da estafa profissional em médicos cancerologistas brasileiros. Rev. Assoc. Med. Bras. [Internet]. 2006.

[42] .Panagioti M; Geraghty K; Johnson J, et al. (2018). Association Between Physician Burnout and Patient Safety, Professionalism, and Patient Satisfaction. JAMA Internal Medicine.doi:10.1001/jamainternmed.2018.3713 [internet] 2018.

[43] Manoel de Carvalho, Alan A. Vieira. Erro médico em pacientes hospitalizados. J. Pediatr. (Rio J.) [Internet]. 2002.

[44] Good BJ \& Good MD 1993. "Learning medicine": the construction of medical knowledge at Harvard Medical School, pp. 81-107. In S Lindenbaum \& M Lock (org.). Knowledge, power and practice: the anthropology of medicine and everyday life. University of California Press, Berkeley.

[45] Atkinson P 1995. Medical talk and medical work: the liturgy of the clinic. Sage Publications Inc., Londres.).

[46] Hotimsky SN, Schraiber L B. Humanização no contexto da formação em obstetrícia. Ciênc. saúde coletiva [Internet]. 2005 Sep.

[47] Mendonca VS; Custodio EM. 0 erro médico e o respeito às vítimas. Bol. psicol, São Paulo, v. 66, n. 145, p. 123134, [internet] jul. 2016.

[48] Coutinho, Mário; LI, Shih Min. Como ter acesso à literatura médica. In: DRUMMOND, José Paulo; SILVA, Eliézer; COUTINHO, Mário. Medicina baseada em evidências: novo paradigma assistencial e pedagógico. 2. ed. São Paulo: Atheneu, 2004. Cap. 2.

[49] Atallah, A. N. Medicina Baseada em Evidências. Revista Diagnóstico \& Tratamento, v. 23, ed 2, 2018).

[50] Organização Mundial de Saúde - OMS. Maternidade segura. Assistência ao parto normal: um guia prático. [Internet] Genebra: OMS, 1996[cited 2017 Feb 4].

[51] Silva DC, Rodrigues ARGM, Pimenta CJL, Leite ES - Perspectiva das puérperas sobre a assistência de enfermagem humanizada no parto normal. REBES[Internet]. 2015.

[52] Thom DH, Rortveit G. Prevalence of postpartum urinary incontinence: a systematic review. Acta Obstet Gynecol Scand. 2010; 89:1511-22.

[53] Yeniel A0, Petri E. Pregnancy, childbirth, and sexual function: perceptions a and facts. Int Urogynecol J. 2014;25(1):5-14

[54] Mendes EPB. Oliveira SMJV; Caroci AS, Amorim AF; Oliveira SG, Silva RL. Força muscular do assoalho pélvico em primíparas segundo o tipo de parto: estudo transversal [internet] 2016.

International Journal of Research -GRANTHAALAYAH 
[55] Borges BB, Serrano F, Pereira F. Episiotomia: uso generalizado versus selectivo. Acta Médica Portuguesa 2003 fev; (16): 447-54.

[56] Graham ID. Episiotomy: challenging obstetric interventions. London: Blackwell Science; 1997. The American crusade for prophylactic episiotomy; chap.3, p. 33-41.

[57] Lago T, Lima LP. Assistência à gestação, ao parto e puerpério: diferenciais regionais e desigualdades socioeconômicas. In: BRASL. Ministério da Saúde. Pesquisa Nacional de Demografia da Saúde da Criança e da MulherPNDS 2006: dimensões no processo reprodutivo e da saúde da criança. Brasília, 2006:151-70.

[58] Alperin, M., Krohn, M. A., \& Parviainen, K. (2008). Episiotomy and Increase in the Riskof Obstetric Laceration in a Subsequent Vaginal Delivery. Obstetrics \& Gynecology, 111(6), 1274-1278.

[59] Amorim MM, Coutinho IC, Melo I, Katz L. Selective episiotomy vs. implementation of a nonepisiotomy protocol: a randomized clinical trial. Reprod Health. 2017;14(1):55.

[60] Parpinelli MA, Surita FG, Pacagnella RC, Simões R. Federação Brasileira das Associações de Ginecologia e Obstetrícia Assistência ao Trabalho de Parto [internet] 2009

[61] Petrucce1 LFF, Oliveira LF, Oliveira VR, Oliveira SR. Femina Vol 45 P 212 - no4- 2017 ISSN 0100-7254 [internet] 2017.

[62] Métodos de Indução do Trabalho de Parto, cap 40, [internet] 2004)

[63] Ministério da Saúde. Secretaria de Políticos de Saúde. Área Técnica de Saúde da Mulher. Parto, aborto e puerpério: assistência humanizada à mulher/ Ministério da Saúde, Secretaria de Políticas de Saúde, Área Técnica da Mulher. - Brasília: Ministério da Saúde, 2001. [internet] 2001. 